Limnological Review (2013) 13, 1: 3-11

DOI 10.2478/limre-2013-0001

\title{
Comparison of iron fractions on the regulated and restored parts of the Rudnia River (NE Poland)
}

\author{
Adam Cudowski, Piotr Zieliński \\ Department of Hydrobiology, Institute of Biology, University of Białystok, Świerkowa 20B, 15-950 Białystok, Poland, \\ e-mail: cudad@uwb.edu.pl (corresponding author)
}

\begin{abstract}
Hydrochemical investigations focusing on different iron fractions were conducted in 2007 from January to December on two parts (regulated and restored) of the small lowland Rudnia River in north-eastern Poland. Concentrations of the total iron (TFe) in the water of the Rudnia River ranged from $582 \mu \mathrm{g} \mathrm{dm}{ }^{-3}$ up to $3646 \mu \mathrm{g} \mathrm{dm}^{-3}$, and their elevated values are clearly the result of their complex binding with organic matter originating from the peat-mineral catchment of the river. Regardless of the season, in the upper part of the river (regulated channel) higher concentrations of all iron fractions than in the restored river section were observed. All tests on iron fractions showed a clear seasonal variability on both river channel parts. Higher TFe concentrations were typical for the regulated part of the river in autumn or winter, and lower in spring for the restored river channel section. For the whole of the investigated period and regardless of the season, particulate iron fraction $(\mathrm{PFe})$ represented a higher proportion of TFe in the regulated channel than in the restored one. PFe constituted up to $60 \% \mathrm{TFe}$, on average, while the other two fractions about $20 \%$ of TFe each. However, dissolved reactive iron fraction (DRFe) made up a larger percentage of TFe than organic soluble fraction (DOFe) of iron within the year. The maximum percentage of DOFe fraction outside the growing season was caused by iron release from organic complexes and elevated concentrations of dissolved organic carbon (DOC) derived from wetlands.
\end{abstract}

Key words: iron, restoration, river, iron fractions, water quality

\section{Introduction}

Iron is one of the main elements that compose the earth's crust. It ranks in fourth place in terms of its amount after oxygen, silica, and aluminum. Its small amount can be found as numerous ores: limonite, siderite, magnetite, hematite, getite, maghemite, ferrohydrite, lepidocronite, ilmenite or pyrite (Kabata and Kabata 1999).

The main iron sources for natural waters are leachates from soils and rocks. Referring to anthropogenic sources, iron ions can penetrate to surface waters along with sewage from metallurgical, galvanizing, or etching works. The Fe element shows typical siderophilic and chalkophilic features and it occurs mainly as bi and trivalent forms in surface waters. Among soluble bivalent iron forms are $\mathrm{Fe}^{2+},[\mathrm{FeOH}]^{+}$, and $\left[\mathrm{Fe}(\mathrm{OH})_{3}\right]$. In waters characterized by large amounts of carbonates or sulphates (VI), the element may be present as $\mathrm{FeSO}_{4(\mathrm{aq})}, \mathrm{FeCO}_{3(\mathrm{aq})}$, or $\left[\mathrm{FeHCO}_{3}\right]^{+}$. In the case of soluble trivalent iron ions, it can be found in the form of $\mathrm{Fe}^{3+},[\mathrm{FeOH}]^{2+},\left[\mathrm{Fe}(\mathrm{OH})_{2}\right]^{+}$, or $\left[\mathrm{Fe}(\mathrm{OH})_{4}\right]^{-}$. If sulphates
(VI), chlorides, or phosphates (V) are present in water in larger amounts, ions of iron (III) are converted into $\left[\mathrm{FeSO}_{4}\right]^{+},\left[\mathrm{Fe}\left(\mathrm{SO}_{4}\right)_{2}\right]^{-},\left[\mathrm{FeHSO}_{4}\right]^{2+},[\mathrm{FeCl}]^{2+},\left[\mathrm{FeCl}_{2}\right]^{+}$, $\left[\mathrm{FeHPO}_{4}\right]^{+}$, or $\left[\mathrm{FeH}_{2} \mathrm{PO}_{4}\right]^{2+}$ (Dojlido 1987).

Iron can occur in the surface waters in various forms: as soluble or colloidal forms. Concentrations of a particular fraction depend on many different factors. The main ones which determine iron form are content of organic matter, redox potential, $\mathrm{pH}$, and presence of loamy minerals (Kabata and Kabata 1979). Another factor determining the form and quantity of iron in the water is microbial activity (Aristovskaya and $\mathrm{Za}$ varzin 1971). The iron circulation in aquatic ecosystems depends on oxygen, sulphur, and carbon transformations. Oxidizing conditions and at the same time alkaline reaction favour the precipitation of the element in the form of numerous compounds, e.g. oxides. Iron oxides in colloidal form play an important role during coagulation and sorption of the other colloidal substances and ions. The colloidal fraction of iron oxides is very important in sewage purification, because these compounds act as catalysts in oxidation process- 
es (Jenne 1968). In an acidic environment and under reductive conditions, solubility of iron compounds dramatically increases. Within the $\mathrm{pH}$ range from 4.8 to 6.0 , these ions bind mainly anions, while above that limit, cations are also bonded. The presence in the water of chemoautotrophic and acidophilic Acidithiobacillus ferrooxidans bacteria oxidizes $\mathrm{Fe}$ (II) to $\mathrm{Fe}$ (III) 5-6 times faster than in abiotic environments, thus the ion can be found at both valences in water below $\mathrm{pH}$ 4.0 (Migaszewski and Gałuszka 2007).

Iron is an example of an element that occurs very abundantly in soils. Light sandy soils contain

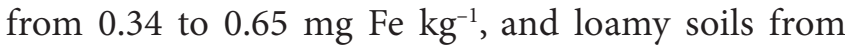
70.0 to $362 \mathrm{mg} \mathrm{Fe} \mathrm{kg}^{-1}$ (Pondel et al. 1979). Iron content in low-moor peat bogs ranges from 57.0 to 830.0 mg Fe kg ${ }^{-1}$ (Brożek and Zwydak 2003).

Processes of iron transformations in aquatic ecosystems are very complex and mainly depend on redox conditions. Therefore, the element affects other metals (namely trace elements) by binding them (including manganese). Depending on different redox conditions in the iron-manganese concretions there occurs a competitive reaction between iron ions and other elements such as cobalt, copper, nickel, which affects the formation of insoluble precipitates. The increase in iron concentration results in increased migration of magnesium and aluminum, because its elevated mobility causes the replacing of the cations mentioned above from their compounds (Khattack and Page 1992).

The aim of this paper is to present the influence of the restoration of the lowland Rudnia River on the composition of different iron fractions and to evaluate the seasonal changes in these fractions on both investigated river parts (regulated and restored). The other aim is to describe the dependence between iron fractions in the water and other physicochemical parameters which affect the bio-availability of different fractions of iron in lotic ecosystems.

\section{Study Area}

The Rudnia River is a right tributary of the Narew River, which is the largest river in north-eastern Poland. The investigated river is $23.2 \mathrm{~km}$ in length and has an average annual flow rate of $0.2 \mathrm{~m} \mathrm{~s}^{-1}$. The Rudnia is a second order river (according to the Horton-Strachler system). The springs of the Rudnia River are situated at 160 metres above sea level in Pasynki village, while the confluence with the Narew River at
130 metres above sea level. Morphological data for the Rudnia River and its catchment are presented in Table 1 and Figure 1 (Zieliński et al. 2008).

Table 1. Morphological characteristics of the Rudnia River and its catchment

\begin{tabular}{lll}
\hline Parameter & Unit & Value \\
\hline River length & $\mathrm{km}$ & 28.8 \\
Average discharge & $\mathrm{m} \mathrm{s}^{-1}$ & 0.2 \\
Catchment area & $\mathrm{km}^{2}$ & 90.57 \\
Catchment slope & $\% o$ & 0.72 \\
Catchment afforestation & $\%$ & 19.09 \\
\hline
\end{tabular}

In the 1970's, the Rudnia River was extensively regulated, mainly in its middle and upper sections. In the ending part of the Rudnia the river channel was shortened by a direct connection with the Narew River through a crosscut of $250 \mathrm{~m}$ in length. The excluded Rudnia river channel gradually became overgrown with macrophytes and it has functioned as an ox-bow lake for about 25 years. In 1998-1999, The North Podlasie Association for Bird Protection (PTOP) began to try to recover the old part of the river. Restoration of the Rudnia's natural course was made by screening off the artificial river channel with a dike.

The catchment of the investigated river is characterized by a high agricultural coverage ratio with a dominance of arable lands, pastures and meadows. In the patchy structure of the catchment typical for this type of catchment the level of afforestation is only about 20\% (Table 1). Besides numerous small-sized patches of forests and extensively cultivated fields, there are small urban areas mostly in the upper part of the Rudnia River catchment eg. Zabłudów town (Fig.1).

\section{Methods}

Field investigations were carried out once a month in 2007. Water samples were collected from 9 points along the Rudnia River's course - 5 monitoring points were located on the regulated part of the Rudnia River (1-5) and 4 others on the restored section (6-9) (Fig. 1) (Zieliński et al. 2008).

Temperature, electrical conductivity, water $\mathrm{pH}$ and oxygen were measured using a multiparametrical Hydrolab probe. Chlorophyll a concentrations were measured applying a chlorophyll field fluorescence probe. 


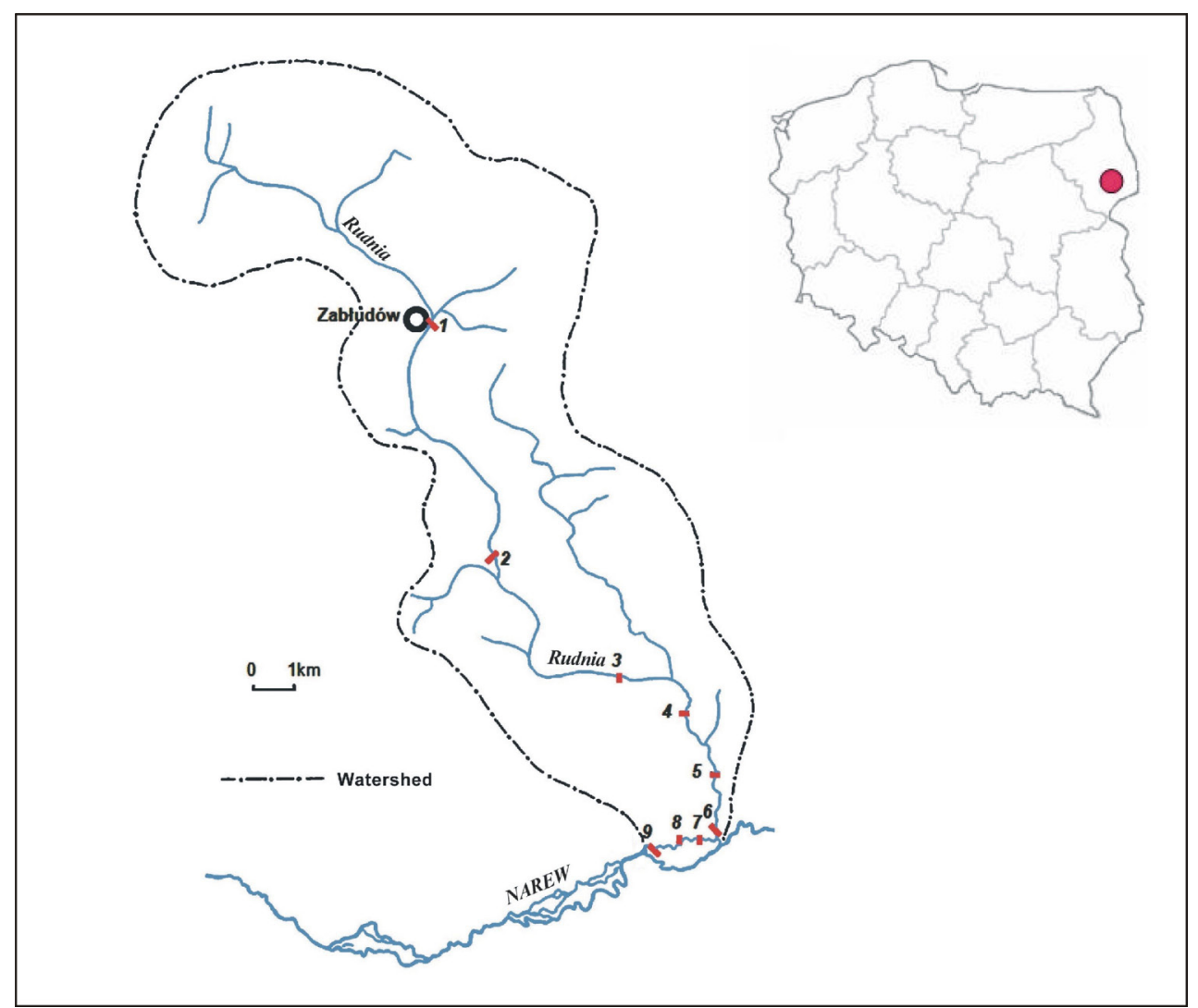

Fig. 1. Map of the Rudnia River catchment with location of sampling points.

Laboratory analyses were made according to methods described by Hermanowicz et al. (1976). The following parameters were determined: bicarbonates - alkacimetrically; total hardness and calcium - complexometrically by titration; magnesium - calculated from the difference between total hardness and calcium concentration; other ions, i.e. nitrates (V), chlorides, sulphates (VI), silicates, and ammonia - spectrophotometrically applying procedures and chemicals by Riedel-de Häen. Dissolved organic carbon concentration (DOC) was determined using total organic carbon analyser TOC 5050A (Shimadzu) according to the procedure described by Zieliński and Górniak (1999). Furthermore, the concentration of reactive manganese in the Rudnia River water was determined with the spectrometric formaldehyde-oxym method (modified) (Cudowski and Górnaik 2006), as well as 3 phosphorus fractions: total phosphorus (TP), dissolved phosphorus (DP), and dissolved reactive phosphorus (DRP) using the spectrophotometric molybdenum-blue method. Concentrations of different iron fractions - total iron (TFe), dissolved iron (DFe) and dissolved reactive iron (DRFe) - were analysed by applying the spectrophotometric method with 1,10-phenantroline. The contents of the two former phosphorus and iron fractions were determined in water samples after UV digestion with concentrated sulphuric (VI) acid and 30\% hydrogen peroxide. Total concentrations of phosphorus and iron were determined in unfiltered, digested water samples, whereas concentrations of dissolved reactive (DRFe, DRP) fractions were determined after filtering through the filter of $0.45 \mu \mathrm{m}$ pore diameter without digestion. Using data for all three determined fractions of phosphorus and iron, subsequently the other two - dissolved organic and particulate - were calculated using the formulas as follows:

$$
\begin{aligned}
& \text { DOX }=\mathrm{DX}-\mathrm{DRX} \\
& \text { or } \\
& \mathrm{PX}=\mathrm{TX}-\mathrm{DX}, \\
& \text { where: } X=\mathrm{Fe}, \mathrm{P} .
\end{aligned}
$$




\section{Results and Discussion}

Mean concentrations of iron fractions and standard deviations for 2007 in particular investigated parts of the Rudnia River are presented in Table 2. The lowest values of total iron in the restored part of the river were noted in October $\left(582 \mu \mathrm{g} \mathrm{dm}^{-3}\right)$ and in January for the regulated part $\left(719 \mu \mathrm{g} \mathrm{dm}^{-3}\right)$, which was over two times less than average total iron concentration in the upper section and over 2.5-times less than average TFe concentration in the lower section of the river (Fig. 1). Within the regulated section, TFe concentrations were higher during the whole year than in the restored one, and the mean difference between both sections was $681 \mu \mathrm{g} \mathrm{dm}{ }^{-3}$. High iron concentrations in the water of the Rudnia River water may be explained by the fact that over $60 \%$ of the river water is supplied from groundwaters, in which average iron content is over $750 \mu \mathrm{g} \mathrm{dm}{ }^{-3}$ higher. Another factor determining large concentrations of iron in the river is its washing out from the surrounding soils, mainly peat, which dominate in the lower riverine catchment part, while more mineral soils cover the upper part of the river catchment.

The fraction of dissolved iron (DFe) in the restored section reached its lowest value in December $\left(206 \mu \mathrm{g} \mathrm{dm}^{-3}\right)$, while in the regulated part in January $\left(426 \mu \mathrm{g} \mathrm{dm}^{-3}\right)$. The highest concentration of that fraction in the lower part of the river was recorded in July $\left(672 \mu \mathrm{g} \mathrm{dm}^{-3}\right)$, whereas in March in the upper part $\left(807 \mu \mathrm{g} \mathrm{dm}^{-3}\right.$ ) (Fig. 2A). The regulated fragment of the river - as compared to the restored section - was characterized throughout the year by concentrations higher by $79 \mu \mathrm{g} \mathrm{dm}^{-3}$, on average. The dissolved iron fraction, regardless of the river part, was characterized throughout the year by much higher variability than TFe, which was over 1.5 times higher for dissolved than for total iron (Fig. 2B). The highest variability, for both fractions, was observed in summer, the low- est in the winter. No statistically significant differences in dissolved iron variability in the two different river sections were found.

Dissolved reactive iron concentration in the lower part of the river ranged from 124 to $453 \mu \mathrm{g} \mathrm{dm}{ }^{-3}$, while in the upper part from 167 to $535 \mu \mathrm{g} \mathrm{dm}^{-3}$. Minimum values of reactive iron concentrations in both river sections were present in December, whereas maximum ones in July (Fig. 2C). Reactive iron in the regulated part was characterized by great dynamics of concentrations in particular months, thus lack of stability contrasted to the restored section, where spring was characterized by an increase in the fraction level until summer when a decrease in DRFe concentration occurred. Beginning from autumn, a gradual increase in iron content could be observed, and then a decrease in winter (analogously as in summer).

Comparing the variability of all iron fraction concentrations, it can be stated that particulate and total iron fractions were characterized with the highest fluctuations during the year (Fig. 2D). The coefficient of variation (CV) for PFe was up to $998 \%$ in the regulated section, while in the restored part $532 \%$. The restored part of the Rudnia River was distinguished by much higher stability of the dissolved fraction than that found in the regulated part. For the whole year $\mathrm{CV}$ values for $\mathrm{DFe}$ in the restored section were 2-3 times lower than in the regulated one, on average. DFe was the least variable iron fraction (regardless of the river channel type), for which the CV value was 55\%. However, it should be mentioned that higher oscillations of that iron fraction occurred in winter than in other seasons.

Regardless of the season, the particulate fraction made up the largest percentage among the total iron (Fig. 3). In winter, that fraction reached its maximum value, with its share in the regulated fragment being $80 \%$, while in the restored one $68 \%$. Such a high percentage of that fraction can be elucidated by fa-

Table 2. Mean iron concentrations with standard deviations in the Rudnia River

\begin{tabular}{llll}
\hline Iron fraction & $\begin{array}{l}\text { Whole Rudnia River } \\
{\left[\mu \mathrm{g} \mathrm{dm}^{-3}\right]}\end{array}$ & $\begin{array}{l}\text { Regulated section } \\
{\left[\mu \mathrm{dm}^{-3}\right]}\end{array}$ & $\begin{array}{l}\text { Restored section } \\
{\left[\mu \mathrm{dm}^{-3}\right]}\end{array}$ \\
\hline TFe & $1558 \pm 1028$ & $1892 \pm 821$ & $1211 \pm 328$ \\
DFe & $581.8 \pm 248.0$ & $604.8 \pm 45.5$ & $525.7 \pm 74.0$ \\
DRFe & $314.5 \pm 151.9$ & $325.1 \pm 120.0$ & $261.5 \pm 101.3$ \\
PFe & $976 \pm 920$ & $1307 \pm 778$ & $664.8 \pm 323.9$ \\
ODFe & $267.3 \pm 242.8$ & $289.0 \pm 130.0$ & $266.7 \pm 67.3$ \\
\hline
\end{tabular}



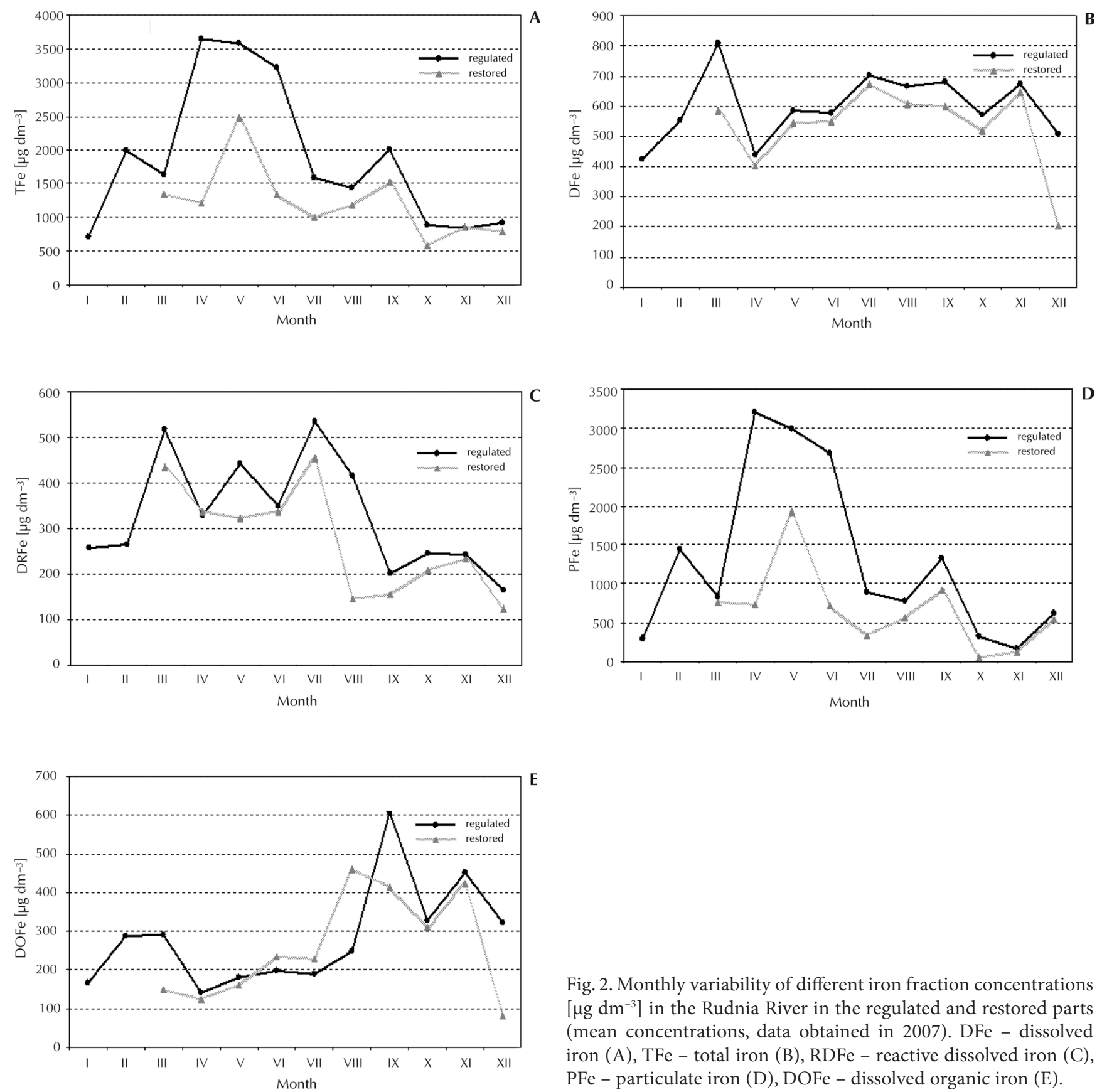

Fig. 2. Monthly variability of different iron fraction concentrations [ $\mu \mathrm{g} \mathrm{dm}^{-3}$ ] in the Rudnia River in the regulated and restored parts (mean concentrations, data obtained in 2007). DFe - dissolved iron (A), TFe - total iron (B), RDFe - reactive dissolved iron (C), $\mathrm{PFe}$ - particulate iron (D), DOFe - dissolved organic iron (E).

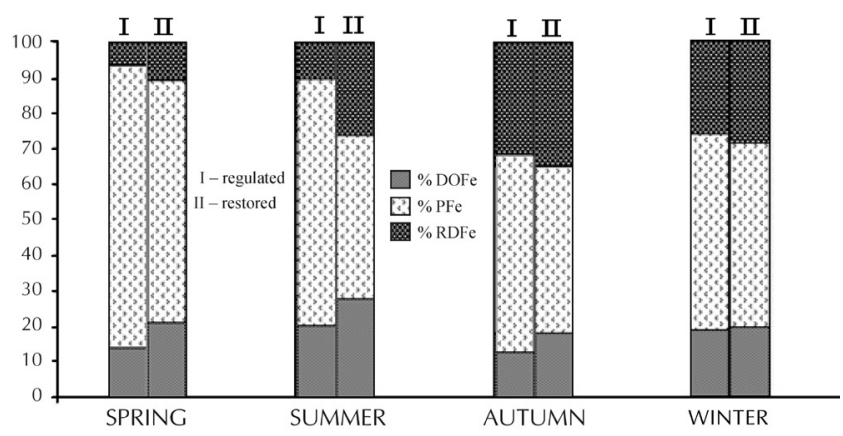

Fig. 3. Seasonal changes in the iron fraction proportions [\%] in total iron in the regulated and restored parts of the Rudnia River depending on the season of 2007. 
vourable conditions (average oxygen concentration in water was $10 \mu \mathrm{g} \mathrm{dm}^{-3}$ ) that favour the precipitation of colloidal iron oxides. The percentage of that fraction gradually decreased along with the season change. The participation of the particulate iron fraction in the restored section reached minimum $46 \%$, whereas the minimum value in the regulated fragment was $56 \%$ (autumn-winter). When the percentage of the particulate iron fraction decreased, the percentage of the other iron forms increased (Fig. 3). Despite the fact that high values of dissolved organic carbon (DOC) reaching up to $23.0 \mathrm{mg} \mathrm{dm}^{-3}$ were observed in July, the reactive iron fraction made up the highest proportion - by $7 \%$ more than DOMn, because a low oxygen concentration was recorded in the water that season (Table 3 ). This was the result of redox conditions (mean oxygen concentration in the water was almost 3 times lower than in the spring season), which determined the iron fraction composition in the river. In autumn, the organic iron fraction reached its maximum percentage: it was only $35 \%$ in the restored and $31 \%$ of total iron in the regulated section. The maximum percentage of the fraction is probably the effect of elevated DOC concentrations (Table 2). Summer was the season when the maximum percentage of the reactive iron forms was recorded, regardless of the river parts, and it amounted to $30 \%$ in the restored, and $22 \%$ in the regulated, section. Differences in the percentage (depending on river channel section) could be explained by differences in oxygen concentrations in the water. A higher level of that fraction was observed in the restored part of the river, because oxygen concentration was higher in the regulated part by $1.5 \mathrm{mg}$ $\mathrm{dm}^{-3}$. Regardless of the season, the shares of reactive and organic iron fractions were always higher in the restored than the regulated section. The suspended iron fraction was characterized by a higher percentage in the lower river bed fragment rather than in the part of the river near the source.
In our investigations we have found that reactive manganese concentrations (ranging from 23 to $164 \mu \mathrm{g} \mathrm{dm}^{-3}$ in 2007), may have a significant influence on reactive iron content in the river. A statistically significant dependence between RDFe and RDMn at $\mathrm{R}^{2}=0.61, \mathrm{p}<0.005$ was recorded in the studied period (Fig. 4A). It is commonly known that both ions form iron-manganese concretions (Sadowski 1997). We observed that variation in reactive manganese concentrations depends on reactive iron content variability. The increase in RDMn in the restored section and its decrease in the regulated part which were recorded in this investigation were analogous as in the case of reactive iron fraction. Regardless of the type of the river section, relatively good water saturation and slightly alkaline conditions stimulate the release of reactive fractions of both elements.

Phosphorus is another parameter the occurrence of which significantly affects the iron concentration in the Rudnia River. Under natural conditions, iron is not present in water in its dissolved form, although it is soon precipitated, converting into insoluble compounds, which is probably as a protection for aquatic ecosystems against an excessive increase in iron concentration (Kabata-Pendias and Pendias 1979). High phosphorus concentrations in water cause precipitation of iron (III) in a form of phosphate (V) iron (III). If the iron is precipitated from the water column, a decrease in reactive manganese content is suddenly observed, and thus an increase in its colloidal fraction. Loss of one of the soluble fractions of these elements leads to their release from other insoluble combinations (Fig. 4B). The observed strong correlation between TP and TFe concentrations proves that the most important factor regulating phosphorus concentration is their release from organic compounds deposited in the sediments and surrounding organic soils (Petticrew and Arocena 2001; Rydin 2000).

Table 3. Mean concentrations (with standard deviations) of selected parameters in various seasons in the Rudnia River

\begin{tabular}{llllll}
\hline \multirow{2}{*}{ Season } & $\mathrm{pH}$ & Oxygen & $\mathrm{DOC}$ & $\mathrm{TP}$ & $\mathrm{DRMn}$ \\
\cline { 3 - 6 } & & {$\left[\mathrm{mg} \mathrm{dm}^{-3}\right]$} & {$\left[\mathrm{mg} \mathrm{dm}^{-3}\right]$} & {$\left[\mu \mathrm{dm}^{-3}\right]$} & {$\left[\mu \mathrm{dm}^{-3}\right]$} \\
\hline Spring & $7.34 \pm 0.17$ & $11.6 \pm 2.0$ & $9.27 \pm 2.26$ & $168.5 \pm 64.6$ & $82.4 \pm 25.1$ \\
Summer & $7.24 \pm 0.21$ & $5.45 \pm 2.03$ & $9.64 \pm 7.02$ & $214.3 \pm 76.2$ & $93.7 \pm 31.8$ \\
Autumn & $7.60 \pm 1.46$ & $5.89 \pm 3.64$ & $11.4 \pm 1.9$ & $111.3 \pm 49.5$ & $60.8 \pm 19.0$ \\
Winter & $7.30 \pm 0.36$ & $7.92 \pm 1.63$ & $6.98 \pm 2.45$ & $142.6 \pm 66.0$ & $38.6 \pm 16.2$ \\
\hline
\end{tabular}



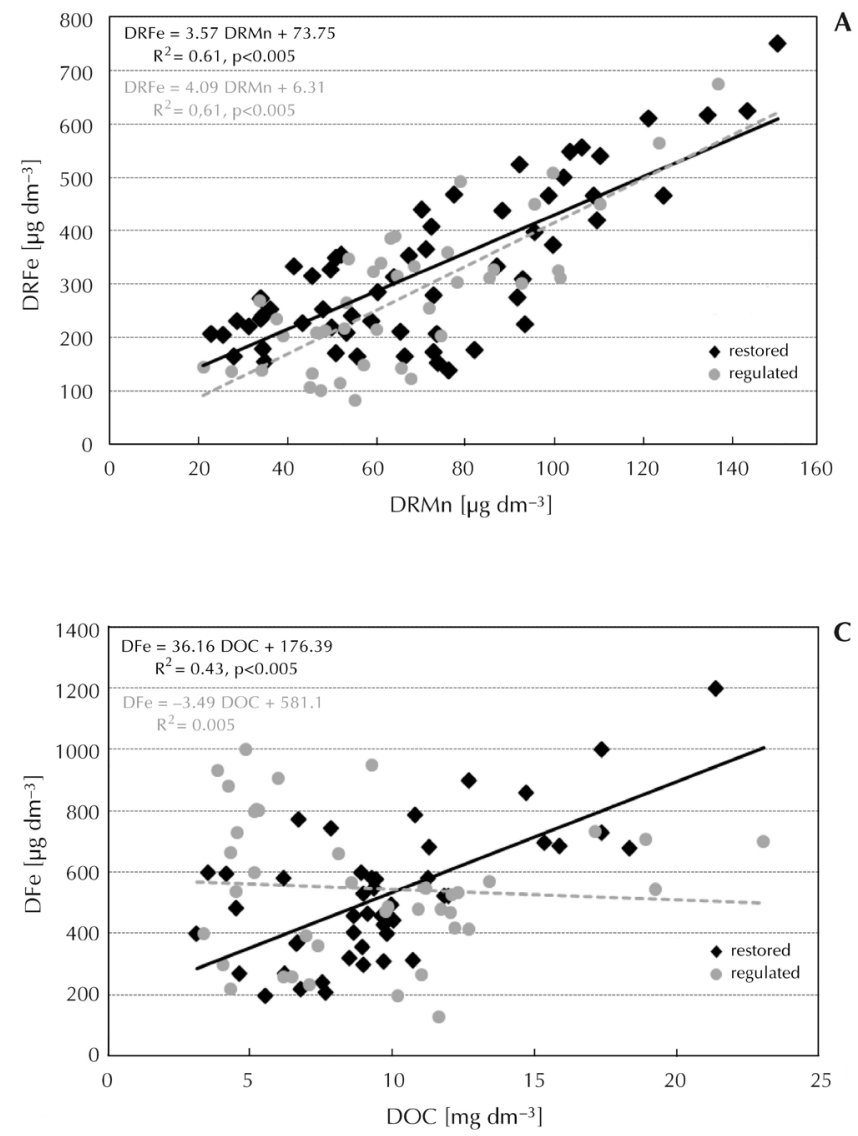

The most important statistically significant correlation $(\mathrm{p}<0.005)$ that was recorded in water for the Rudnia River was a positively proportional dependence between dissolved organic matter and the dissolved organic iron fraction. That association can be elucidated by the fact that iron is an element that easily forms bindings with organic compounds. As a confirmation, there was a proportional dependence between DOFe and DOC, for which the coefficient of determination was $44 \%$ (Fig. 4C). The dependence between dissolved organic matter and the organic iron fraction can be explained by the tendency of iron ions to bind with organic matter, which prevents the precipitation of insoluble phospho-organic compounds (Sapek and Sapek 2004).

When the water temperature drops (autumn and winter), the rate of microbial decomposition of organic matter slows down along with the decrease in plant plankton's requirements for $\mathrm{Mn}^{2+}$, which is codeposited on the surface with $\mathrm{Fe}^{3+}$ forming iron-manganese concretions. The process of iron-manganese concretion formation is related with decomposition

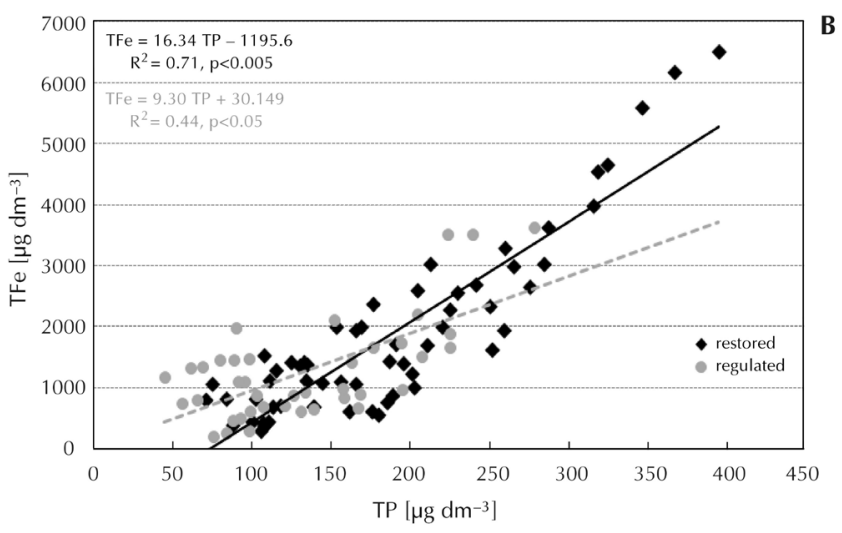

Fig. 4. Correlations between dissolved reactive iron fraction (DRFe) and analysed chemical parameters: A - total phosphorus (TP), B - reactive dissolved manganese, $\mathrm{C}$ - dissolved organic carbon (DOC) of the Rudnia River water in 2007 on both the restored and regulated parts.

of plankton organic matter and release of these ions in the bottom sediments layer (Sadowski 1997). Much more iron is released from organic bindings than is immobilized in inorganic compounds. The process results in a higher percentage of the reactive iron fraction (DRFe) in cold seasons (4-fold higher percentage of DRFe in autumn than in spring). Moreover, under the ice cover, reactive iron is released from its mineral precipitates, e.g. $\mathrm{Fe}_{2} \mathrm{O}_{3}$ or $\mathrm{Fe}_{3} \mathrm{O}_{4}$ present since the summer on the surface of sediments, which of course leads to an increase in DRFe concentration.

Even if iron concentrations are high in the Rudnia River they are comparable with values noted for other streams and rivers in the region and Poland, where they range from 15 up to over $3000 \mu \mathrm{g} \mathrm{dm} \mathrm{dm}^{-3}$ (Table 4).

The percentage of dissolved reactive and dissolved organic iron fractions was always lower in the regulated than in the restored part of the Rudnia River in all investigated seasons. Furthermore, the regulated part of the river was characterized by a higher share of suspended iron fraction content than the restored 
Table 4. Iron concentrations (in $\mu \mathrm{g} \mathrm{dm}^{-3}$ ) in selected Polish and foreign rivers

\begin{tabular}{lll}
\hline River & Concentration & References \\
\hline Bystra & $15-340$ & $\begin{array}{l}\text { Kabata-Pendias and Bolibrzuch } \\
(1979)\end{array}$ \\
Mała Panew & $721-3185$ & Pasternak (1974) \\
Jaroszówka & $75-305$ & Jekatierynczuk-Rudczyk (2010) \\
Yangtze & $168-224$ & Fan et al. (2008) \\
Ubá & $631-3326$ & Jordão et al. (2002) \\
Vistula & $120-1140$ & Zimna (1976) \\
Supraśl & $10-2876$ & Skorbiłowicz (2010) \\
Mississippi & $56-448$ & Shiller (1997) \\
Babia Góra & $320-2980$ & Zieliński et al. (2006 ) \\
Narew & $20-7270$ & Zieliński and Górniak (2006) \\
\hline
\end{tabular}

one for the whole year. No matter the season, the upper part of the river was distinguished by higher iron concentrations than the lower part (Fig. 2A-D), which was due to the fact that many farms polluting water with iron as a result of surface runoffs from cultivated fields and orchards were localized in the upper fragment of the river catchment. Iron fertilizers are commonly applied in plant and tree cultivation, because iron deficiency causes a serious disease - leaf chlorosis - that may lead to plants fading (Eichhorn and Shin 1968). Municipal sewage that penetrates into the waters through strongly corroded pipes is another source of water contamination. Lowland rivers with well-developed wetland areas, including the Rudnia River with its lower fragment, are a transport system for well-dissolved organic matter of allochtonic origin (Wetzel 2001), thus the increase in the dissolved organic iron fraction was observed on that part of the river bed. It is due to the fact that iron ions migrate along with organic carbon compounds from wet areas of the catchment (Petticrew and Arocena 2001).

\section{Conclusions}

Concentration of total iron ranged from 581.7 to $3646 \mu \mathrm{g} \mathrm{dm}^{-3}$ in the water of the small lowland Rudnia River, and the values obtained were similar to those for other lowland rivers.

The highest percentage of TFe was represented by the particulate iron fraction, while the lowest, depending on the season, by the dissolved reactive iron fraction in spring-summer, and the dissolved organic iron fraction (DOFe) in autumn-winter.
Iron resources in the river are determined mainly by migration of iron compounds along with organic matter during spring and autumn surface runoffs as well as decomposition of riverine plant-origin detritus in summer and autumn.

The increased percentage of reactive iron fraction content in autumn-winter is a result of the ion release from mineral precipitates formed in the summer on the river sediment's surface.

\section{Acknowledgements}

This work was part-funded by the Polish Ministry of Science and Higher Education project no. 3T09D06929.

\section{References}

Aristovskaya T.V., Zavarzin G.A., 1971, Biochemistry of iron in soil, [in:] McLaren A.D., Skujins J.J. (eds), Soil Biochemistry. Vol. 2, Marcel Dekker, New York: 385-408.

Brożek S., Zwydak M., 2003, Atlas gleb leśnych Polski (Atlas of forest soils of Poland). Centrum Inf. Lasów Państwowych, Warszawa, p. 466 (in Polish).

Cudowski A., Górniak A., 2006, Effects of Narew River damming in the Siemianówka Reservoir on manganese forms in river water, Pol. J. Environ. Stud. 15(5D, Part II): 457-461.

Dojlido J., 1987, Chemia wody (Chemistry of water), Arkady, Warszawa, p. 352 (in Polish).

Eichhorn G.L., Shin Y.A., 1968, Interaction of metal ions with polynucleotides and related compounds, J. Am. Chem. Soc. 90: 7323-7328.

Fan D.J., Neuser R.D., Sun X.G., Yang Z.S., Guo Z.G., Ziai S.K., 2008, Authigenic iron oxide formation in the estuarine mixing zone of the Yangtze River, Geo. Mar. Lett. 28: 7-14.

Hermanowicz W., Dożańska W., Dojlido J., Koziorowski B., 1976, Fizyczno-chemiczne badania wody i ścieków (Physico-chemical examination of water and wastewater), Arkady, Warszawa, p. 418 (in Polish).

Jekatierynczuk-Rudczyk E., 2010, Przekształcenie składu fizyczno-chemicznego płytkich wód podziemnych w strefach drenażu na obszarach nizinnych (Transformation in physico-chemical composition of groundwaters within lowland drainage zones), Wyd. UwB, Białystok, p. 224 (in Polish, English summary).

Jenne E.A., 1968, Controls on $\mathrm{Mn}, \mathrm{Fe}, \mathrm{Co}, \mathrm{Ni}, \mathrm{Cu}$ and $\mathrm{Zn}$ concentration in soils and water, Adv. Chem. 73: 337387.

Jordão C.P., Pereira M.G., Pereira J.L., 2002, Metal contamination of riverwaters and sediments from effluents of kaolin processing in Brazil, Water Air Soil Poll. 140: 119-138. 
Kabata-Pendias A., Bolibrzuch E., 1979, Pierwiastki śladowe w wodach dorzecza rzeki Bystrej, Wyżyna Lubelska (Trace elements in the water of Bystra river basin, Lublin Upland), Roczn. Gleb. 30: 107-123 (in Polish).

Kabata-Pendias A., Pendias H., 1979, Pierwiastki śladowe w środowisku biologicznym (Trace elements in the biological environment), Wyd. Geol., Warszawa, p. 300 (in Polish).

Kabata-Pendias A., Pendias H., 1999, Biogeochemia pierwiastków śladowych (Biogeochemistry of trace elements), PWN, Warszawa, p. 397 (in Polish).

Khattack R.A., Page A.L., 1992, Mechanism of manganese adsorption on soil constituents, [in:] Adriano D.C. (ed.), Biolgeochemistry of trace elements, Lewis Publishers, Boca Raton: 383-400.

Migaszewski Z.M., Gałuszka A., 2007, Podstawy geochemii środowiska (Basis of environmental geochemistry). Wyd. Nauk.-Tech., Warszawa, p. 574 (in Polish).

Pasternak K., 1974, Wpływ zanieczyszczeń huty cynku w Miasteczku Śląskim na zawartość mikroelementów w środowisku wód powierzchniowych (Influence of pollutants from a zinc mill in Miasteczko Śląkie on the content of microelements in the environment of surface waters), Acta Hydrobiol. 16: 273-297 (in Polish, English summary).

Petticrew E.L., Arocena J.M., 2001, Evaluation of iron-phosphate as a source of internal lake phosphorus loadings, Sci. Tot. Envi. 266: 87-93.

Pondel H., Terelak H., Terelak T., Wilkos S., 1979, Właściwości chemiczne gleb Polski (Chemical properties of soils in Poland), Pam. Puł., 71 Supl.: 52-63 (in Polish).

Rydin E., 2000, Potentially mobile phosphorus in lake Erken sediment, Water Res. 34(7): 2037-2042.

Sadowski Z., 1997, Biogeochemia żelaza i manganu (Biogeochemistry of iron and manganese), Wiad. Chem. 53: 11-12 (in Polish).

Sapek A., Sapek B., 2004, Wymywanie składników nawozowych $\mathrm{z}$ odwodnionych gleb torfowych po ich renaturalizacji (Leaching of nutrients from the drained peat soils after restoration), [in] Popek Z., Wasilewicz M. (eds) Bliskie Naturze Kształtowanie Dolin Rzecznych (Close to Nature Forming of River Valleys), Wyd. SGGW, Warszawa: (in Polish).
Shiller A.M., 1997, Dissolved trace elements in the Mississippi River: Seasonal, interannual, and decadal variability, Geochim. Cosmochim. Acta 61: 4321- 4330.

Skorbiłowicz M., 2010, Czynniki i procesy kształtujące obieg składników mineralnych w wodach rzecznych zlewni górnej Narwi (Factors and processes shaping the circulation of mineral components in the riverine waters of the upper Narew river basin). Wyd. Politechniki Białostockiej, Białystok, p.159 (in Polish).

Wetzel R.G., 2001, Limnology. Lake and river ecosystems, Acad. Press, San Diego, p. 1066.

Zieliński P., Górniak A., 1999, Analizy rozpuszczonego węgla organicznego w wodach naturalnych, (Analyses of dissolved organic carbon in natural waters), Aparat. Bad. Dydakt. 3: 37-45 (in Polish, English summary).

Zieliński P., Górniak. A., 2006, Charakterystyka limnologiczna Narwi powyżej zbiornika, (Limnological characteristic of Narew river before the Siemianówka Reservoir), [in:] Górniak A. (ed.), Ekosystem zbiornika Siemianówka w latach 1990-2004 i jego rekultywacja (Ecosystem of the Siemianówka Reservoir in the years 19902004 and its restoration), Wyd. UwB, Białystok: 39-53 (in Polish).

Zieliński P., Górniak A., Jekatierynczuk-Rudczyk E., 2006, Cechy hydrochemiczne bezpośrednich dopływów do zbiornika Siemianówka (Hydrochemical characteristics of direct tributaries to the Siemianówka Reservoir), [in:] Górniak A. (ed.), Ekosystem zbiornika Siemianówka w latach 1990-2004 i jego rekultywacja (Ecosystem of the Siemianówka Reservoir in the years 1990-2004 and its restoration), Wyd. UwB, Białystok: 53-55 (in Polish).

Zieliński P., Jekatierynczuk-Rudczyk E., Górniak A., 2008, Changes in dissolved organic carbon concentration in renaturalized lowland river, Limnol. Papers 3: 69-77.

Zimna D., 1976, Badania nad formami żelaza występującego w wodach ujściowych Wisły i przybrzeżnych Zatoki Gdańskiej (Investigations of the forms of iron present in the Vistula estuarian and coastal waters of the Gulf of Gdansk), Stud. Mater. Oceanol. 14 (Chemia Morza 2): 172-198 (in Polish, English summary). 